\title{
Menyusur Dua Alur Lukisan Jelekong
}

\author{
Danuh Tyas Pradipta* \\ KK Estetika dan ilmu-IImu Seni, Fakultas Seni Rupa dan Desain, Institut Teknologi \\ Bandung, Indonesia
}

\begin{abstract}
Jelekong is the name of a village located in Kabupaten Bandung. The name of this village has become widely known due to its the paintings produced by its residents. These paintings are well known for their depiction of landscape, animals and flowers. Later, through several Jelekong painters, another kind of painting has emerged. This emergence of another type of painting, not only raises diversity in its thematic and techniques. It also shows the differences in how the painting is produced, distributed and appreciated, and also how Jelekong painter transforms their practice.

To simplify the identification, these two kinds of paintings will be referred to as "traditional" Jelekong painting and "contemporary" Jelekong painting. The emergence of both kinds of paintings, with all its difference, shows one fundamental thing: the differences of the artworld. Those kinds of artworld substantially caused all these differences between both kinds of Jelekong paintings.

This paper aims to further the elaboration between both of the paintings that developed in Jelekong. To elaborate all the difference, this paper focused on the sociology aspect of art which underlies both the two kinds of paintings. Sanento Yuliman's thesis, Dua Seni Rupa, will be mobilised as the analytical framework for this paper.
\end{abstract}

Keywords: traditional painting, contemporary painting, Jelekong, artworld, dua seni rupa

$\begin{array}{ll}\text { *Danuh Tyas Pradipta } \\ \text { Email } & : \text { danoeht@gmail.com } \\ \text { Address } & \text { KK Estetika dan Ilmu-IImu Seni, Fakultas Seni Rupa dan Desain } \\ & \text { Institut Teknologi Bandung } \\ & \text { Jalan Ganesha no.10, Bandung, West Java - Indonesia } 40132\end{array}$




\section{Menyusur Dua Alur Lukisan Jelekong}

Danuh Tyas Pradipta

\section{PENDAHULUAN}

Kampung wisata Jelekong terletak di Kampung Giriharja, Kelurahan Jelekong, Kecamatan Baleendah, Kabupaten Bandung. Berjarak sekitar 15 km selatan Kota Bandung. Sebagai sebuah kampung wisata, daerah ini memiliki berbagai ciri khas yang menjadi daya tariknya. Di dalam kampung ini terdapat beberapa komunitas kesenian yang hidup dan beraktifitas, beberapa bahkan sudah berlangsung turun-temurun. Salah satu yang paling dikenal adalah komunitas seni wayang golek Giriharja. Komunitas ini sudah berlangsung selama beberapa generasi dan reputasinya sudah dikenal tidak saja dalam skala lokal, tapi juga nasional bahkan internasional. Selain komunitas wayang golek, terdapat juga komunitas seni lainnya, seperti: pencak silat dan seni tari.

Salah satu komunitas seni lain yang sangat dikenal dan sudah menjadi ikon kampung Jelekong adalah seni lukis. Melukis sudah menjadi aktifitas keseharian sebagian masyarakat Jelekong. Mulai diperkenalkan di Jelekong sejak tahun 1970-an, melukis perlahan-lahan menjadi salah satu mata pencaharian utama masyarakat Jelekong hingga saat ini. Sebagai sebuah mata pencaharian, aktifitas melukis di Jelekong dengan sendirinya berkaitan erat dengan perkara ekonomi.

Bagi sebagian masyarakat Jelekong, melukis adalah mata pencaharian utama. Aktifitas melukis mereka, pertama-tama sangat berkait erat dengan mekanisme ekonomi (produksi-distribusi-konsumsi) ketimbang pada perkara proses kreatifitas dan penciptaan karya seni. Artinya, segala usaha pembuatan lukisan selalu didasari atas pertimbangan ekonomi: bagaimana selera pasar, bagaimana lukisan harus dibuat untuk mengikuti selera tersebut, bagaimana pelukis dapat memenuhi jumlah permintaan lukisan, dan sebagainya.

Puluhan tahun, melukis menjadi kegiatan yang menyatu dengan keseharian masyarakat Jelekong. Seiring waktu, lukisan-lukisan hasil kerja tangan masyarakat Jelekong tidak saja terdistribusi di sekitar Bandung, tapi juga sudah menyeberang pulau hingga ke daerah Bali bahkan hingga ke mancanegara. Namun, seiring dengan itu, belakangan muncul kecenderungan lain dalam aktifitas melukis di Jelekong. Sebagian masyarakat Jelekong saat ini melukis dengan gagasan dan orientasi yang berbeda dengan apa yang sudah berlangsung turun-temurun. Melukis bagi mereka, tidak lagi semata untuk memenuhi pesanan dari pembutuh dan ajeg pada pesanan selera artistik para pembutuh. Berbeda dari itu, melukis bagi mereka adalah cara mengekspresikan gagasan dan cara pandang mereka terhadap berbagai persoalan di sekitar mereka. Sehubungan dengan itu, lukisan yang mereka hasilkan dengan sendirinya memiliki ciri dan bahasa ekspresi yang berbeda dengan lukisan Jelekong pada umumnya. Lebih dari itu, lukisan mereka pun dengan sendirinya masuk ke dalam alur yang berbeda, di luar alur produksi-distribusikonsumsi pada umumnya lukisan Jelekong.

Kedua alur dalam kegiatan melukis di Jelekong inilah yang akan menjadi objek bahasan dalam tulisan ini. Melalui tulisan ini akan dipaparkan apa dan bagaimana kedua alur itu, serta aspek-aspek perbedaaan diantara keduanya.

\section{TRADISI LUKIS JELEKONG}

Perkenalan masyarakat Jelekong terhadap kegiatan melukis dimulai sejak tahun 1970an. Dirintis oleh tokoh setempat: Odin Rohidin, yang memulai kegiatan melukis sebagai sebuah mata pencaharian, perlahan-lahan melukis mulai dipraktekan oleh 
masyarakat Jelekong dan mulai menjadi salah satu mata pencaharian utama masyarakat setempat. Dalam konteks itu, kegiatan melukis di Jelekong boleh saja disebut sebagai sebuah 'tradisi', meski bukan dalam arti usianya yang uzur dan dilakukan turun-temurun sejak nenek moyang.

Rochman Nur S. melalui wawancara dengan seorang perintis pembuatan lukisan di Jelekong, dalam skripsinya yang berjudul Lukisan Desa Jelekong Kabupaten Bandung menulis bahwa pada mulanya kegiatan melukis dirintis sebagai upaya mewujudkan citra berkesenian bagi masyarakat Jelekong. Melukis dimaksudkan sebagai perbendaharaan lain dalam berkesenian, selain jenis kesenian lain yang sudah ada dan eksis sebelumnya, seperti seni pentas, seni pedalangan, seni pencak silat [1] .

Melukis dapat dilihat sebagai sebuah 'tradisi' dalam masyarakat Jelekong, karena sejak dimulai sekitar 40 tahun yang lalu, kegiatan itu masih terus dilakukan sampai hari ini oleh sebagian masyarakat di sana. Bahkan tidak jarang, keterampilan melukis diturunkan dari satu generasi ke generasi berikutnya dalam satu keluarga. Keterampilan melukis itu, tidak didapat secara formal, dalam arti melalui pendidikan seni rupa di perguruan tinggi. Keterampilan itu lebih sering didapat dan terasah dari hasil pengalaman melukis yang dilakukan terus-menerus. Keterampilan itu juga seringkali didapat melalui sebuah "sistem pengajaran" semacam sanggar.

Sistem itu terjadi ketika seorang pemula yang ingin belajar melukis, kemudian membantu di sanggar/studio salah satu pelukis yang lebih senior. Di sana, tidak sekedar membantu melukis lukisan pesanan, para pemula itu seringkali juga harus melalui proses pembelajaran lebih dulu. Mereka diberi tugas bertahap, dari mulai membuat dan menyiapkan kanvas, membuat sketsa, menyiapkan dan mencampur cat hingga akhirnya melukis lukisan pesanan. Teknik melukis, utamanya dipelajari para pemula dengan meniru apa yang dilakukan para seniornya. Proses pembelajaran macam itu juga adalah salah satu cara terjadinya penurunan/pewarisan keterampilan melukis dari generasi senior kepada generasi yang lebih junior dan menyebabkan kegiatan melukis terus hidup di Jelekong, berserta terus malarnya regenerasi pelukis di sana.

Di dalam skripsi Rochman Nur, dapat ditemukan pula beberapa peran yang mungkin dijalankan oleh para pelukis di Jelekong. Peran-peran tersebut, dapat dibagi menjadi: pelukis sekaligus sebagai penampung pekerja, pelukis dengan pemodalan sendiri dan pelukis yang sebagai pekerja. Bukan saja keterampilan melukis, tema, gubahan, serta cara melukis juga menjadi bagian yang diturunkan oleh generasi tua. Maka, bukan hal yang aneh bila apa yang dihasilkan para pelukis hari ini tidak jauh berbeda dengan apa yang sudah pernah dilakukan pada masa-masa sebelumnya [1].

Apa yang dikenal dengan sebutan 'lukisan pemandangan' adalah salah satu hasil dari pewarisan itu. Tema pamandangan alam menjadi ciri khas -sekaligus stereotip- dari tradisi lukis Jelekong. Tema itu adalah yang pertama kali diperkenalkan di sana, dan menjadi yang paling populer di kalangan pelukis Jelekong. Sebagai variasi, adapula tema-tema lain yang dibuat oleh para pelukis Jelekong, misalnya: tema bunga, binatang dan lukisan abstrak. Tema binatang adalah tema yang jamak di lukis setelah pemandangan alam. Binatangbinatang seperti burung, kuda, ikan koi adalah yang paling sering dijadikan objek lukisan. Hal yang menarik, contohnya dalam melukis kuda dan ikan koi selalu ada pakem-pakem yang tidak bisa ditinggalkan. Melukis kuda, harus berjumlah 8 dan dalam posisi sedang berlari, sementara ikan koi selalu berjumlah 9 sedang berkumpul dalam kolam.

Semua tema itu dikerjakan dengan beberapa teknik melukis yang juga sudah diperkenalkan secara turun-temurun. Ada nyoret (menggores dengan pisau palet), cokcrok (menutul dengan kuas) dan spons (menorah dengan ujung bekas sandal jepit, karet timba atau busa yang diruncingkan). Tentu, berbagai teknik dan peralatan yang dipakai itu tidak bisa terhindar dari peralihan, modifikasi atau inovasi. 


\section{MENYEBAL TRADISI: ALUR LAIN LUKISAN JELEKONG}

Sebagai sebuah tempat yang memiliki tradisi puluhan tahun memasok lukisan-lukisan ke berbagai daerah dan negara, serta statusnya kini sebagai kampung wisata, para pelukis Jelekong tidak tertutup dari interaksi dengan berbagai pihak di luar kampung mereka. Misalnya, para pelukis itu tidak jarang mendapat undangan untuk memberikan pelatihan (workshop) melukis pada orang-orang di luar kampung mereka.

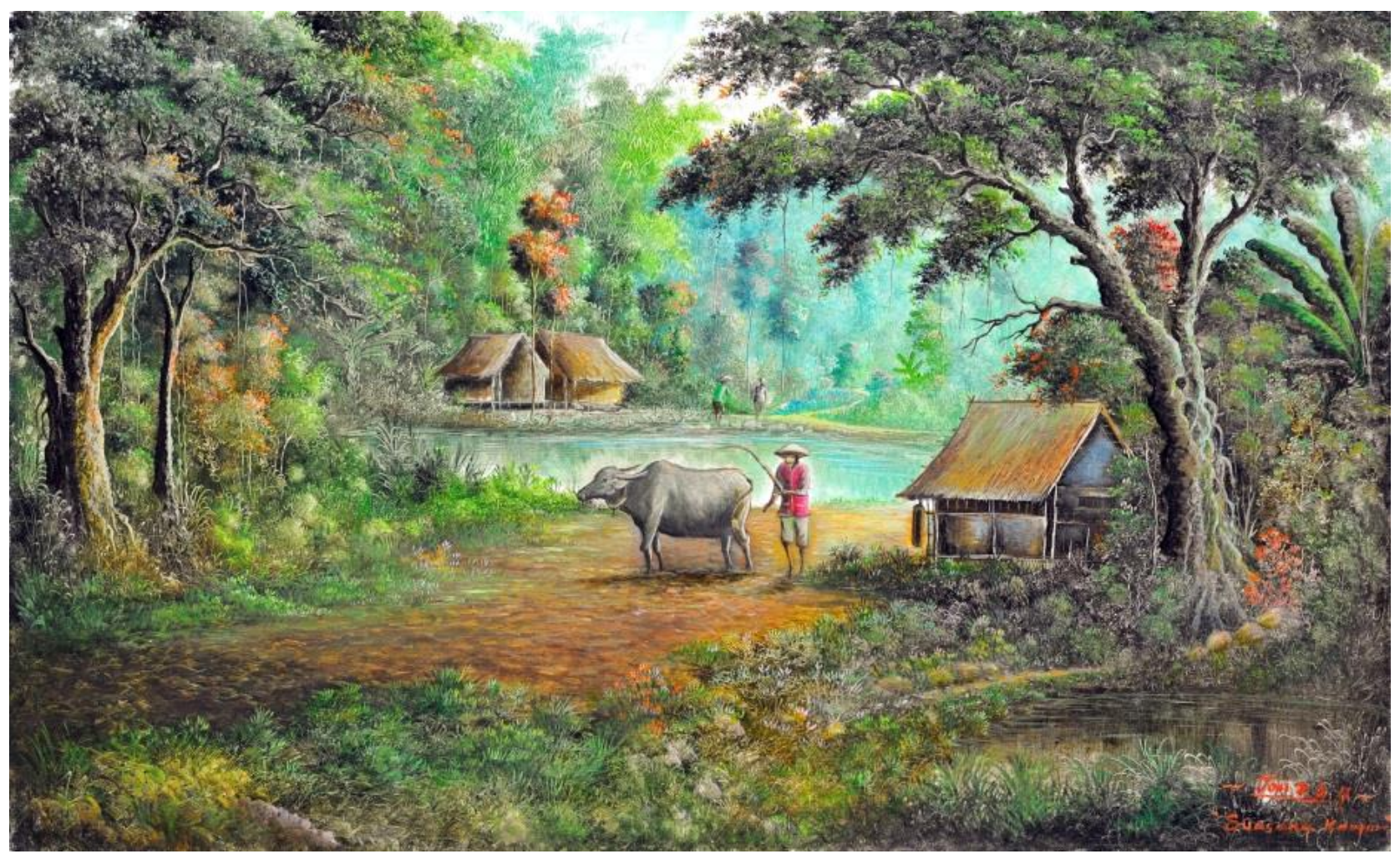

Gambar 1 Toni Diasentara, Suasana Kampung, 2017, cat minyak di kanvas, 90x150 cm. (Sumber: Selasar Sunaryo Art Space)

Interaksi juga terjadi dengan para turis asing yang datang berkunjung ke Jelekong. Tidak saja untuk sekedar melihat-lihat lukisan, para turis ini juga datang untuk membeli langsung lukisan-lukisan Jelekong dan tidak jarang juga untuk belajar melukis. Ada hal lain yang tidak jarang didapat para pelukis Jelekong dari interaksi dengan para turis asing itu, yaitu wawasan tentang seni lukis. Lewat para turis asing itu, para pelukis Jelekong mendapatkan wawasan tentang pelukis-pelukis terkenal dalam sejarah seni rupa Barat serta gaya-gaya lukis yang berkembang di dalamnya. Lewat asupan wawasan itupula, para pelukis Jelekong mencoba mencari pembaruan-pembaruan dan inovasi-inovasi dalam lukisan mereka, meski seringkali itu tidak cukup signifikan karena bagaimanapun pasar lukisan Jelekong sudah memiliki acuan-acuan selera yang khas dan berlangsung sejak dulu.

Wawasan bukan saja hasil yang didapat para pelukis Jelekong dari interaksinya dengan para turis asing tapi juga dengan para pelukis dari luar Jelekong -terutama pelukis akademis. Sebagian pelukis Jelekong tidak saja berinteraksi dengan sesama pelukis Jelekong, tapi melalui jaringan pertemanan mereka juga berinteraksi dengan pelukispelukis lain di luar Jelekong. Di antara pelukis-pelukis itu diantaranya adalah pelukispelukis yang juga mengenyam pendidikan formal di perguruan tinggi seni rupa. Melalui interaksi ini, perlahan-lahan muncul alur lain dalam praktek melukis di Jelekong. Kemunculan lukisan 'yang lain' itu diprakarsai oleh sebagian saja pelukis Jelekong. Beberapa di antaranya aktif dalam komunitas, yang kelak menjadi tempat bertukar informasi, ide dan pengalaman tentang jenis lukisan 'yang lain' itu. 
Kemunculan alur lain dalam melukis di kalangan pelukis Jelekong, sebenarnya bukanlah hal yang luar biasa. Bila kepekaan dan keakraban dengan seni lukis yang telah lama tercipta, bertemu dengan pengetahuan baru yang didapat dari pergaulan yang luas ditambah dengan kemudahan akses informasi, bukan mustahil memunculkan orangorang "nakal" yang menyebal dari tradisi. Sekedar ingin mencoba sesuatu yang lain atau bahkan bosan terhadap tradisi yang sudah lama dilakukan terus-menerus dan ingin beralih pada yang lain. Dorongan ini juga yang nampaknya ada dalam benak sebagian pelukis Jelekong untuk mencoba membuat jenis lukisan yang lain.

Lukisan jenis lain itu memiliki beberapa perbedaan dengan lukisan Jelekong pada umumnya yang sudah dilakukan turun temurun. Dalam hal tematik/ objek lukisan, lukisanlukisan itu tidak lagi berkutat pada pemandangan alam, kumpulan binatang atau bunga. Sebagai gantinya, objek dalam lukisan sangat beragam dengan komposisi rupa yang lebih kompleks dan beragam pula. Keberagaman objek lukisan itu juga memperlihatkan perbedaan yang lain, yaitu dalam hal gagasan melukis. Bagi para pelukis "nakal" itu, lukisan adalah perwujudan dari gagasan dan pandangan mereka terhadap suatu persoalan, lukisan adalah bentuk representasi sebuah persoalan. Karenanya objek-objek dalam lukisan mereka, bisa berkaitan dengan berbagai macam persoalan, dari personal, spiritual, lingkungan, sosial hingga politik.

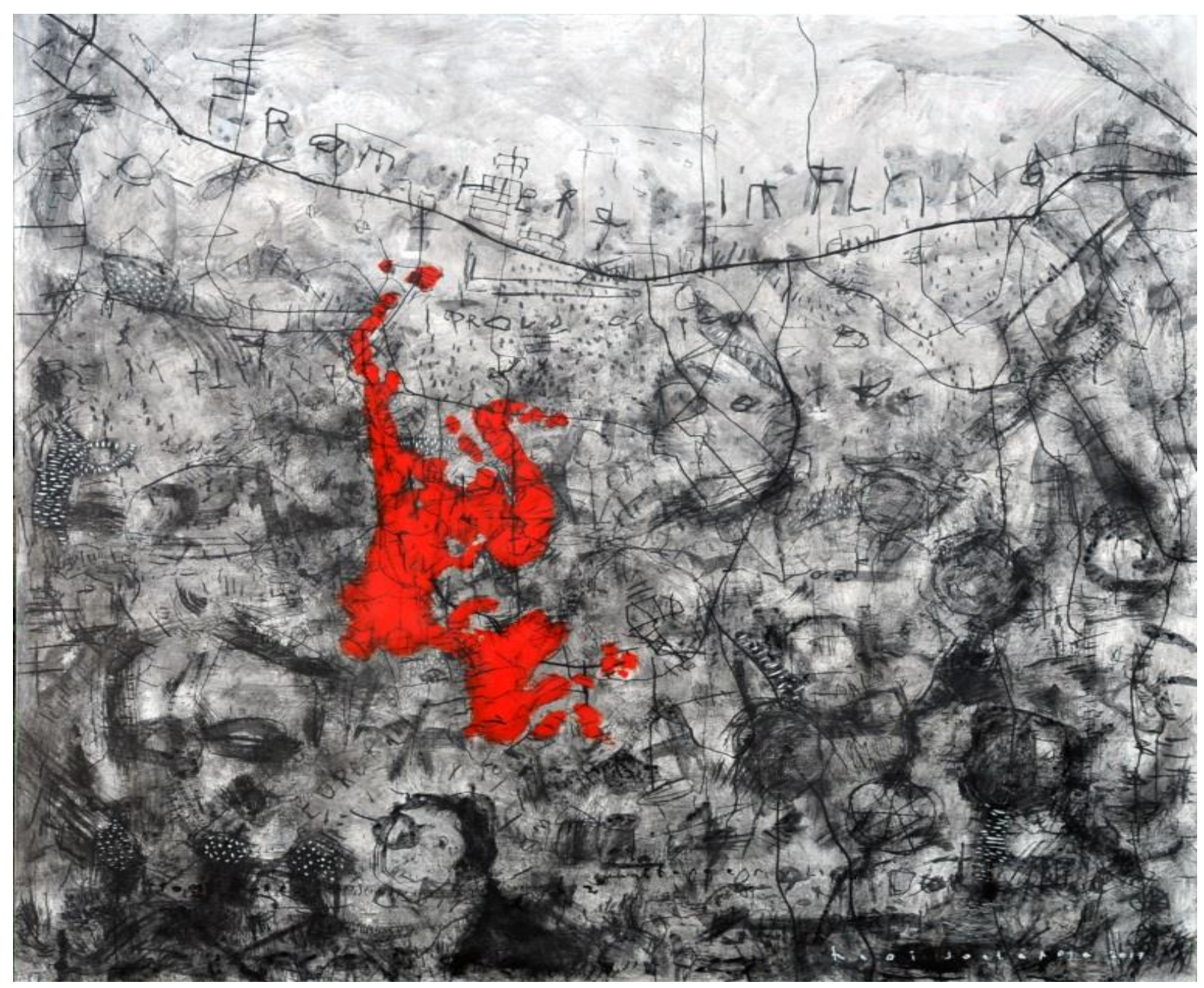

Gambar 2 Hedi Soetardja, Jelekong \#1, 2017, media campur di kanvas, 200x200 cm. (Sumber: Selasar Sunaryo Art Space)

Dalam soal medium lukis, lukisan-lukisan ini tidak jauh beda dengan lukisan-lukisan "tradisional" Jelekong. Cat minyak atau akrilik di atas kanvas masih menjadi pilihan yang umum. Meski begitu, sesekali adapula pelukis yang membuat lukisan dengan medium 
yang berbeda. Misalnya dengan medium campur (mix media) seperti lukisan cat minyak dipadu dengan kolase, atau lukisan tidak lagi terwujud di atas kanvas tetapi bisa di atas papan, plastik bening dan sebagainya. Pemilihan medium tersebut bergantung pada gagasan ekspresi yang ingin disampaikan pelukis.

Pendekatan teknik melukis pun menjadi lebih beragam. Bila pada lukisan-lukisan Jelekong umumnya, pendekatan teknik yang digunakan adalah teknik realis -di mana keterampilan meniru bentuk objek serinci dan semirip mungkin menjadi hal yang utamamaka pada kecenderungan yang baru, pendekatan melukis yang lain bisa dengan leluasa digunakan. Pendekatan teknik melukis ekspresif salah satu yang digunakan para pelukis. Berbeda dengan teknik realis, teknik ekspresif tidak lagi menekankan pada keterampilan meniru bentuk semirip mungkin, melainkan lebih menekankan pada tercurahnya atau terwujudnya emosi yang dirasakan seniman ketika melukis semaksimal mungkin di atas bidang lukis.

Berbagai perluasan itu -dari sisi objek lukisan, penggunaan medium juga teknik melukis- menunjukkan kemunculan alur lain dalam praktek melukis di kalangan pelukis Jelekong. Alur yang secara mendasar mengambil hal yang lain dengan tradisi melukis Jelekong sebelumnya, yaitu dalam hal motif, dorongan atau gagasan dalam melukis. Untuk memudahkan, sebutlah lukisan "lain" Jelekong itu sebagai "lukisan kontemporer" Jelekong.

\section{DUA ALUR LUKISAN JELEKONG: DUA MACAM MEDAN SENI LUKIS}

Kemunculan dua alur lukisan Jelekong itu, tidak saja menunjukkan perbedaan cara dan tema dalam melukis, yang lebih penting hal itu sekaligus menunjukkan perbedaan yang lebih mendasar, yaitu: perbedaan 'medan seni rupa (lukis)'.

Istilah 'medan seni lukis', diperkenalkan oleh kritikus Sanento Yuliman dalam tulisannya Medan Seni Lukis Kita: Permasalahan. Menurutnya, apa yang dinamakan sebagai medan seni lukis adalah sebuah lingkungan pergaulan yang berisi "kekuatan", yang mampu menggerakkan semua orang yang berhubungan dengan seni lukis dan lukisan (pelukis, galeri, kolektor, kritikus, dan lain-lain) bertemu dan berinteraksi. Tentu saja, dalam medan tersebut, seni lukis adalah alasan dan perkara yang utama [2].

Perbedaan medan seni di antara kedua jenis lukisan Jelekong itu, dengan sendirinya akan memberikan perbedaan serta konsekuensi yang signifikan. Perbedaan medan seni, berarti juga adalah perbedaan para pelaku di dalamnya, serta tidak kalah penting: adalah perbedaan berbagai "kekuatan" di dalamnya. Perbedaan tersebut tentu saja akan berpengaruh pada banyak aspek, semisal: motif/tujuan lukisan itu dibuat, siapa yang mengapresiasi, bagaimana cara lukisan itu diapresiasi, bagaimana cara lukisan itu terdistribusi (terjual) dan masih banyak lagi.

Perbedaan pihak yang terlibat dalam medan yang berbeda, berhubungan erat dengan mekanisme medan yang berbeda pula. Sebagai contoh: bila pada lukisan tradisional Jelekong, pihak yang terlibat secara umum menjadi lebih sederhana, seperti pelukis, pengepul/makelar dan pembeli. Alur distribusi lukisan itu pun bergerak pada tiga pihak itu, secara berurut: pelukis-pengepul-pembeli. Mekanisme distribusi tersebut adalah mekanisme yang umum dan sudah berlangsung cukup lama. Sementara itu, lukisan kontemporer Jelekong berada dalam medan yang diisi oleh pihak-pihak yang berbeda. Medan tersebut bisa meliputi lebih banyak pihak, dibanding dengan medan yang satu. Pada medan ini, seorang pelukis bisa berurusan dengan pihak galeri (galeris), kurator, kolektor, kritikus, wartawan, art dealer, bahkan mungkin balai lelang.

Sementara itu, perbedaan "kekuatan" yang berada di dalam kedua medan tersebut, berhubungan dengan motif, tujuan, "modal" serta cara-cara yang digunakan para pelaku dalam berinteraksi di dalam medan. Salah satu unsur yang mempengaruhi perbedaan "kekuatan" dalam medan tersebut, adalah apa yang disebut Pierre Bourdieu dalam teori 
medan artistiknya sebagai habitus. Di dalam bukunya Kurasi dan Kuasa, Agung Hujatnika mengartikan konsep habitus Bourdieu tersebut dengan lebih sederhana, sebagai: konsep yang di satu sisi mengekspresikan cara-cara individu bertindak dan menjadi dirinya sendiri dengan mengembangkan sikap tertentu, di sisi lain adalah cara-cara atau landasan yang digunakan seseorang itu untuk terlibat dalam suatu praktek [3]. Habitus inilah yang mengakibatkan meski ada sesama pelukis asal Jelekong dengan latar belakang keterampilan yang sama, namun ketika berada dalam medan seni lukis yang berbeda, maka motif serta cara-cara yang dilakukannya menjadi berbeda.

Di dalam praktek lukisan tradisional Jelekong misalnya, seorang pelukis memiliki peran sebagai produsen lukisan. Sebagai pelukis, ia tidak dituntut untuk melakukan pembaharuan, eksperimentasi. Sebagaimana yang sudah terjadi turun-temurun, sudah terdapat pola-pola yang khas dari lukisan Jelekong, yang atas nama pasar tidak bisa diabaikan begitu saja. Karenanya seorang pelukis Jelekong dalam melukis lukisan tersebut, ia bisa melukis tanpa acuan apapun, ia sudah menghafal pola-pola lukisan di dalam kepalanya. Sehubungan dengan pola lukisan yang sudah turun-temurun, lukisan mungkin saja dibubuhi tanda tangan pelukisnya, tapi secara visual boleh jadi lukisanlukisan itu tidak menunjukkan ciri khas personal, ekspresi personal pelukis. Ciri khas dan ekspresi personal surut tertutup oleh pola atau pakem lukisan yang sudah khas dan pasti. Kalaupun ada yang membedakan lukisan seorang pelukis/studio yang satu dengan yang lain, mungkin hanya sebatas keterampilan teknik melukis.

Sehubungan dengan distribusi dan konsumsi lukisan tradisional Jelekong, pelukis justru tidak memiliki porsi yang besar. Di dalam alur pelukis-pengepul-pembutuh, proses setelah produksi lukisan dan berhubungan dengan distribusi adalah bagian pengepul. Sosok inilah yang punya posisi untuk menentukan harga jual akhir pada pembutuh. Karenanya, harga jual pada angka yang besar seringkali hanya melibatkan sosok ini dan tidak pada pelukis. Di dalam sistem yang sudah turun-temurun itupun seringkali ada "aturan main" yang dipatuhi oleh seorang pelukis Jelekong, ia tidak perlu tahu-menahu soal bagaimana dan pada siapa lukisannya terjual. Hal tersebut dianggap sudah menjadi wilayah kerja seorang pengepul.

Di sisi lain, di tengah-tengah medan seni lukis yang berbeda dan dengan para agen yang berbeda pula, para pelukis Jelekong dengan lukisan-lukisan kontemporernya diharuskan bersikap secara berbeda. Hubungan-hubungan yang mereka bangun dalam medan ini melibatkan pihak-pihak serta mekanisme yang lebih kompleks. Sebut saja misalnya, sebagai seniman mereka akan berurusan dengan pemilik galeri, kurator, kritikus, art dealer, kolektor dan sebagainynya. Dari segi banyaknya pihak yeng terlibat, medan satu ini nampak melibatkan lebih banyak pihak dengan peran masing-masing yang spesifik. Dengan statusnya sebagai 'seniman' para pelukis Jelekong ini pun memiliki cara kerja yang berbeda, sebagai seniman para pelukis ini justru dituntut untuk menciptakan karya dengan ciri khas personal yang unik, lukisan mereka kemudian lebih sebagai ekspresi personal masing-masing. Oleh karena itu, dalam lukisan mereka ciri khas personal, ekspresi artistik personal menjadi penting. Untuk itu, pelukis selalu dituntut untuk melakukan pembaharuan serta eksperimentasi untuk meningkatkan capaian artistiknya dalam lukisan. Sehubungan dengan itu, acuan melukis bagi pelukis Jelekong tidak lagi hanya dari tradisi yang telah didapatnya selama hidup di Jelekong, pelukis Jelekong dalam medan seni lukis kontemporer dapat melihat acuan dari pelukis sedunia di manapun. Referensi di internet, majalah-majalah serta buku-buku memungkinkan hal itu terjadi. Acuan tersebut seringkali tidak hanya berlaku bagi pembuatan aspek visual, tapi memungkinkan dalam aspek teknik serta material dan medium yang digunakan.

Sehubungan dengan itu, produksi lukisan tidak lagi berkaitan dengan adanya pesanan. Produksi lukisan justru berkait dengan usaha para pelukis itu untuk menunjukan kiprah kesenimanan mereka. Karena itu, para pelukis kontemporer Jelekong tidak lagi mendapat penghasilan rutin dari hasil penjualan lukisan mereka. Penjualan lukisan mereka 
tergantung pada publikasi lukisan mereka pada publik, umumnya lukisan-lukisan itu harus dipamerkan terlebih dulu. Perbedaan lain sehubungan dengan penjualan lukisan, sebagai hasil ekspresi personal yang unik maka dari sekali penjualan sebuah lukisan, para pelukis kontemporer Jelekong justru bisa mendapat hasil yang jauh lebih besar. Mekanisme jual beli ini tidak bisa lepas dari peran galeris, art dealer dan juga kolektor. Karena itu, sebagai seniman, para pelukis kontemporer Jelekong tidak hanya dituntut untuk memproduksi lukisan, tetapi juga dituntut untuk bisa menjalin hubungan dengan galeris, dealer, kolektor dan sebagainya. Perkenalan dan jejaring justru menjadi hal yang penting dalam medan ini.

Perbedaan dua macam seni lukis bagi dua macam lukisan Jelekong di atas, sekaligus bisa menunjukkan bagaimana dua alur dalam lukisan Jelekong tersebut dibuat dan diapresiasi. Perbedaan tersebut dapat pula dilihat dalam kaitannya dengan aspek sosiologis masyarakat kita. Gagasan Sanento Yuliman tentang dua macam seni rupa yang berlangsung di tengah-tengah masyarakat Indonesia bisa digunakan untuk melihat perbedaan sosiologis tersebut.

\section{LUKISAN TRADISIONAL JELEKONG DALAM PERSPEKTIF "SENI RUPA BAWAH" SANENTO YULIMAN}

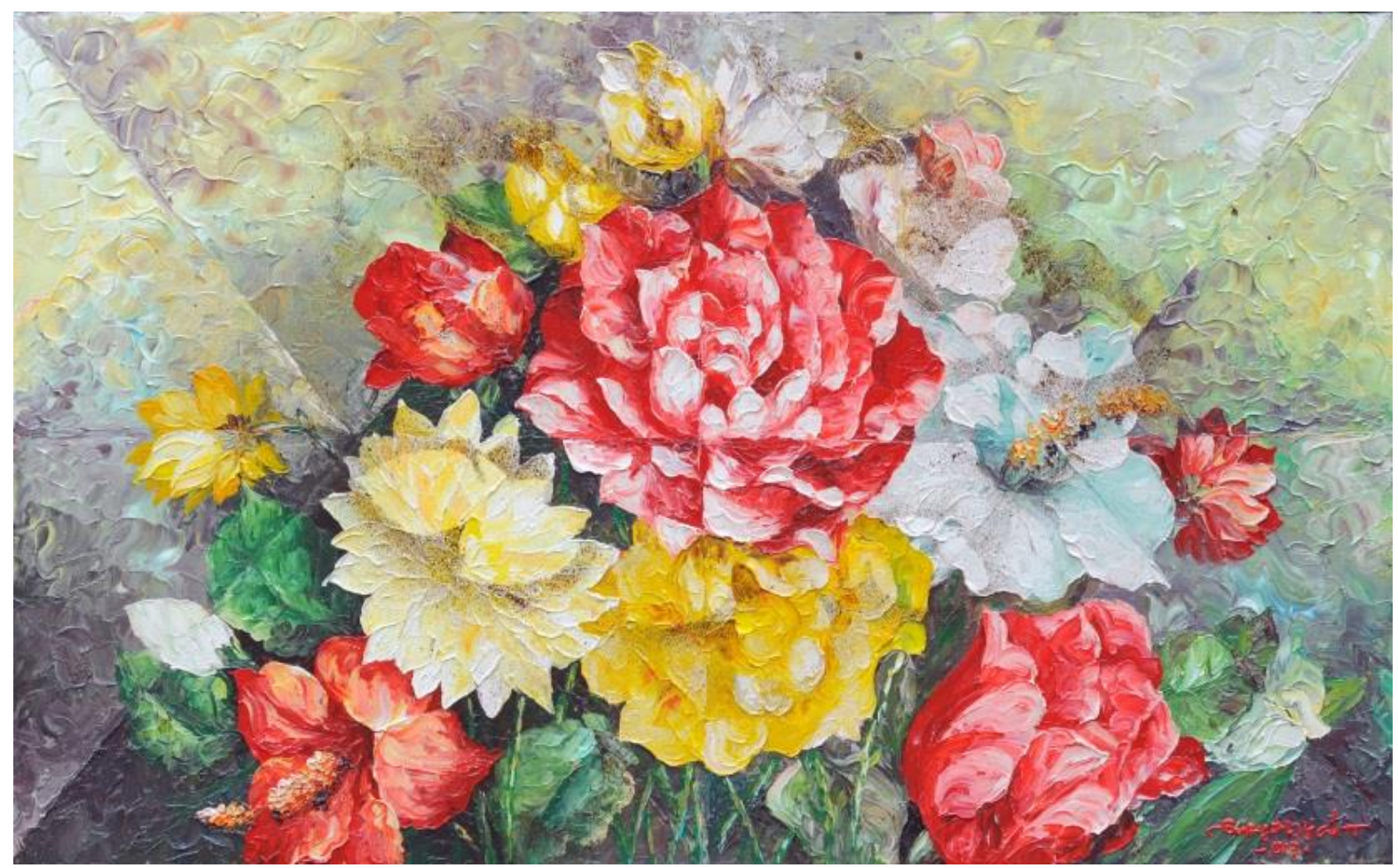

Gambar 3 Didi Suryadi, Bunga dan Komposisi, 2017, cat minyak di kanvas, 90x150 cm. Foto: Selasar Sunaryo Art Space

Di dalam tulisan Dua Seni Rupa, Sanento Yuliman menjelaskan apa yang dia maksud sebagai 'seni rupa bawah' adalah seni rupa yang proses produksi, distribusi dan konsumsinya terjadi di lapisan menengah-bawah, baik di kota besar maupun terutama di kota kecil dan desa. Beredar terutama di lapisan semacam itu, seni rupa ini bertalian dengan ekonomi lemah dan taraf hidup yang rendah serta dipraktekan oleh masyarakat kurang terpelajar (dalam artian tanpa mendapatkan pendidikan formal). Produksi hasil seni rupa bawah, juga bertalian dengan penggunaan cara dan alat sederhana, bahkan sebagian peralatan dibikin secara swadaya (dibikin sendiri).

Di dalam banyak hal, tradisi lukis Jelekong menunjukkan kesamaan dengan karakteristik seni rupa bawah yang diungkapkan Sanento. Para pelukis Jelekong, memperoleh keterampilan mereka tidak melalui pendidikan formal seni rupa atau lukis. Umumnya mereka memperoleh keahlian tersebut dengan belajar pada pelukis yang lebih 
senior, dan mengasahnya dengan cara semakin banyak melukis. Lukisan Jelekong adalah kesenian rakyat yang dilakukan oleh kebanyakan masyarakat di desa Jelekong. Lukisan ini dibuat dengan dorongan utama untuk memenuhi kebutuhan ekonomi dan sebagian besar masyarakat menjadikannya sebagai mata pencaharian. Meski begitu, harga jual lukisan yang tinggi tidak menghinggapi semua pelukis Jelekong, hanya segelintir pelukis senior atau yang juga merangkap peran sebagai pengepul yang bisa merasakan berkah dari harga tinggi lukisan Jelekong. Karenanya, bagi sebagian besar pelukis Jelekong, "tradisi" ini masih erat berkaitan dengan ekonomi lemah dan taraf hidup yang rendah (meskipun persebarannya sudah menggapai luar negeri). Maka, bukan hal aneh bila keluhan tentang rendahnya hasil yang didapat dari penjualan lukisan Jelekong masih menjadi perkara yang jamak di kalangan pelukis Jelekong.

Sebagai pelukis di Jelekong, seseorang tidak saja memiliki keterampilan melukis. Keterampilan lain yang biasa dimiliki diantaranya keterampilan membuat kanvas, spanram (perentang kanvas) hingga meng-oplos cat. Pada beberapa studio, bahkan para pelukis pemula yang akan belajar melukis, terlebih dahulu diberi tugas membuat dan menyiapkan kanvas serta mencampur cat sebelum diberi tugas melukis lukisan pesanan. Menyiapkan sendiri kebutuhan melukis tidak saja pada persoalan kanvas, persoalan cat pun adakalanya seorang pelukis Jelekong juga menyiapkannya sendiri. Ada jenis cat yang digunakan secara turun-menurun oleh pelukis Jelekong, cat tersebut adalah cat cetak (terutama merk 'Peony'). Cat tersebut memilliki harga yang relatif murah dan dapat dibeli dalam jumlah yang banyak, untuk menyiapkannya menjadi cat lukis, maka para pelukis Jelekong terbiasa men-oplos dengan terpentin atau linceed oil. Tidak hanya cat, peralatan lukis juga ada yang mereka buat sendiri. Potongan bekas karet timba atau sandal jepit yang diruncingkan berguna untuk menggurat lukisan sebagai salah satu variasi teknik lukisan Jelekong.

Pada perkara yang berkaitan dengan soal ekonomi, lukisan Jelekong menghadapai persoalan yang masih salalu dikeluhkan oleh para pelakunya, keluhan yang sekaligus terdengar kontradiktif. Di satu sisi, lukisan Jelekong sudah tersebar ke berbagai kota besar di Indonesia, bahkan lebih jauh lukisan tersebut tersebar hingga ke luar negeri, tapi di sisi lain hasil "ketenaran" lukisan Jelekong tersebut tidak sepenuhnya berdampak keuntungan ekonomi bagi seluruh pelukis Jelekong pembuatnya. Perkara itu berkaitan erat dengan sistem pemasaran lukisan Jelekong yang selama ini sudah dilakukan secara malar.

Tradisi lukis Jelekong -sejak dimulainya sampai saat ini- sudah memberikan andil yang cukup penting bagi kehidupan ekonomi masyarakat Jelekong. Para pelukis Jelekong, terutama menempatkan kegiatan melukisnya sebagai mata pencaharian. Sudah banyak warga jelakong yang hidup dan sejahtera dari kegiatan melukis mereka.

Meski begitu, keuntungan dan kesejahteraan ekonomi belum menjadi hal yang merata bagi seluruh pelukis Jelekong. Tidak semua pelukis Jelekong mendulang untung dari usaha lukisan yang mereka jalani. Memang di satu sisi, penyebaran (distribusi) lukisan Jelekong masih malar. Sudah jadi pengetahuan umum, bahwa Jelekong adalah pemasok utama "lukisan-lukisan jalanan" (kerena dijajakan di pinggir jalan) yang ada jalan Braga Bandung. Tidak hanya menjangkau Bandung, lukisan Jelekong juga sudah menyebar ke Cipanas Punca serta Jakarta, bahkan menyeberang pulau hingga ke Bali dan Medan. Bahkan, lukisan-lukisan itu juga sudah tersebar hingga ke luar negeri, seperti Malaysia dan Singapura. Meski begitu, keluhan soal harga jual yang rendah masih menjadi keluhan yang kerap di kalangan sebagian besar pelukis Jelekong.

Penyebaran lukisan Jelekong itu tidak bisa lepas dari kaitannya dengan 'turisme'. Dalam kaitan itu, lukisan Jelekong berfungsi sebagai sebuah cenderamata, oleh-oleh khas dari suatu daerah wisata yang dikunjungi para turis. Penyebaran lukisan Jelekong itu bergerak dalam alur: pelukis-pengepul-toko/artshop/pembeli). Pelukis tentu saja bertugas memproduksi lukisan sesuai pesanan -baik tema maupun jumlahnya. Pengepul 
adalah orang/pihak yang bertugas mengumpulkan lukisan dari beberapa pelukis di Jelekong. la bertugas sebagai penyalur lukisan-lukisan tersebut kepada para pembutuh lukisan. Siapa saja bisa menjalani peran sebagai pengepul, bahkan dari beberapa contoh, pengepul bisa saja diperankan oleh pelukis Jelekong yang sudah lebih "besar" atau mapan. Pelukis-pelukis ini mengordinir beberapa pelukis lain di bawahnya untuk membuat lukisan dalam jumlah dan jangka waktu tertentu dan ia kemudian yang menyalurkan lukisanlukisan itu. Sementara pembutuh lukisan itu, nampaknya bisa perorangan langsung, atau toko-toko yang berada di berbagai tempat wisata. Toko-toko atau artshop inilah yang kemudian akan bertransaksi dengan para turis.

Melalui alur di atas, harga lukisan Jelekong bisa meningkat berkali-kali lipat hingga di tangan terakhir, dengan kata lain seringkali terjadi, harga lukisan yang diterima para pelukis yang memproduksi lukisan sangat kecil jumlahnya. Harga tersebut kemudian bisa berlipat-lipat ketika transaksi terjadi di antara pengepul, toko/artshop dan pembeli. Karenanya, keuntungan dari harga jual lukisa Jelekong tidaklah menyentuh semua pihak. Pengepul dan toko-toko (artshop) seringkali yang kemudian mendapat keuntungan. Kalaupun ada pelukis yang mendapat keuntungan besar, ia biasanya adalah pelukis besar/ternama di Jelekong dan bukan tidak mungkin sekaligus berperan sebagai pengepul lukisan.

Berurusan dengan perkara ekonomi dan turisme, produksi lukisan Jelekong dituntut oleh pesanan dalam jumlah banyak. Maka, bukan hal garib bila dalam seminggu seorang pelukis Jelekong bisa menghasilkan puluhan lukisan dan sebuah lukisan bisa selesai dalam hitungan jam. Meski masih melukis secara manual dan sederhana, pelukis Jelekong dituntut melukis dengan irama kerja yang lebih mekanis dan dalam tempo yang cepat. Di tengah kondisi semacam itu, pelukis Jelekong lebih sering menyebut diri "perajin" ketimbang "seniman". Bagi pelukis yang berperan sebagai pekerja, mengingat hasil yang mereka dapat dari penjualan lukisan tidak seberapa, maka menjadikan membuat lukisan dalam jumlah sebanyak-banyaknya sebagai target adalah hal yang masuk akal. Karena dengan cara itu, secara masuk akal penghasilan yang didapat akan bertambah banyak.

Sehubungan dengan keluhan soal penjualan lukisan Jelekong oleh para pelukis, maka tidak jarang ada pihak yang turun tangan memberi penyuluhan atau pelatihan tentang "kiat-kiat" pemasaran. Hal semacam itu bukanlah hal yang aneh atau langka, bahkan Sanento melihatnya sebagai salah satu karakter dalam seni rupa bawah. la menulis, " la adalah objek kecerdikan pedagang, objek pemerintah dan pembinaan industri... seni rupa bawah adalah seni rupa bawahan" [4].

\section{LUKISAN KONTEMPORER JELEKONG DALAM PERSPEKTIF "SENI RUPA ATAS" SANENTO YULIMAN}

Sebagai lukisan yang memiliki kecenderungan sebagai seni rupa kontemporer, lukisan "kontemporer" Jelekong memiliki karakter yang condong pada apa yang disebut Sanento Yuliman sebagai 'seni rupa atas'. Bagi Sanento, 'seni rupa atas' adalah seni rupa yang kelahiran dan pertumbuhannya sangat besar peranan faktor yang memancar dari negeri berindustri maju, terutama faktor informasi dan konsumsi. Selain itu, seni rupa ini juga berkaitan dengan pertumbuhan lapisan atas dan menengah masyarakat di kota-kota besar. Bahkan para pelaku dari seni rupa ini umumnya berasal dari lapisan sosial menengah dan merupakan lulusan-lulusan pendidikan tinggi seni rupa [4].

Hasil seni rupa atas bisa merupakan produk yang eksklusif atau sebagian lainnya bertalian dengan perdagangan besar dengan konsumen meluas. Menjadi bagian dari seni rupa atas itu, Sanento memasukan seni lukis (rupa) modern serta desain (interior, furniture, grafis, produk) [4].

Dalam beberapa hal, lukisan "kontemporer" Jelekong memiliki beberapa kecenderungan yang bisa dikategorikan pada pengertian di atas -yang membedakannya dengan lukisan "tradisional" Jelekong. Memang, lukisan tersebut masih dibuat atau 
diproduksi di Desa Jelekong. Para pelukis pembuatnya pun adalah para pelukis Jelekong yang tidak memiliki latar belakang pendidikan formal seni rupa. Meski begitu, patut diingat bahwa para pelukis itu mendapatkan gagasan-gagasan dan dorongan untuk

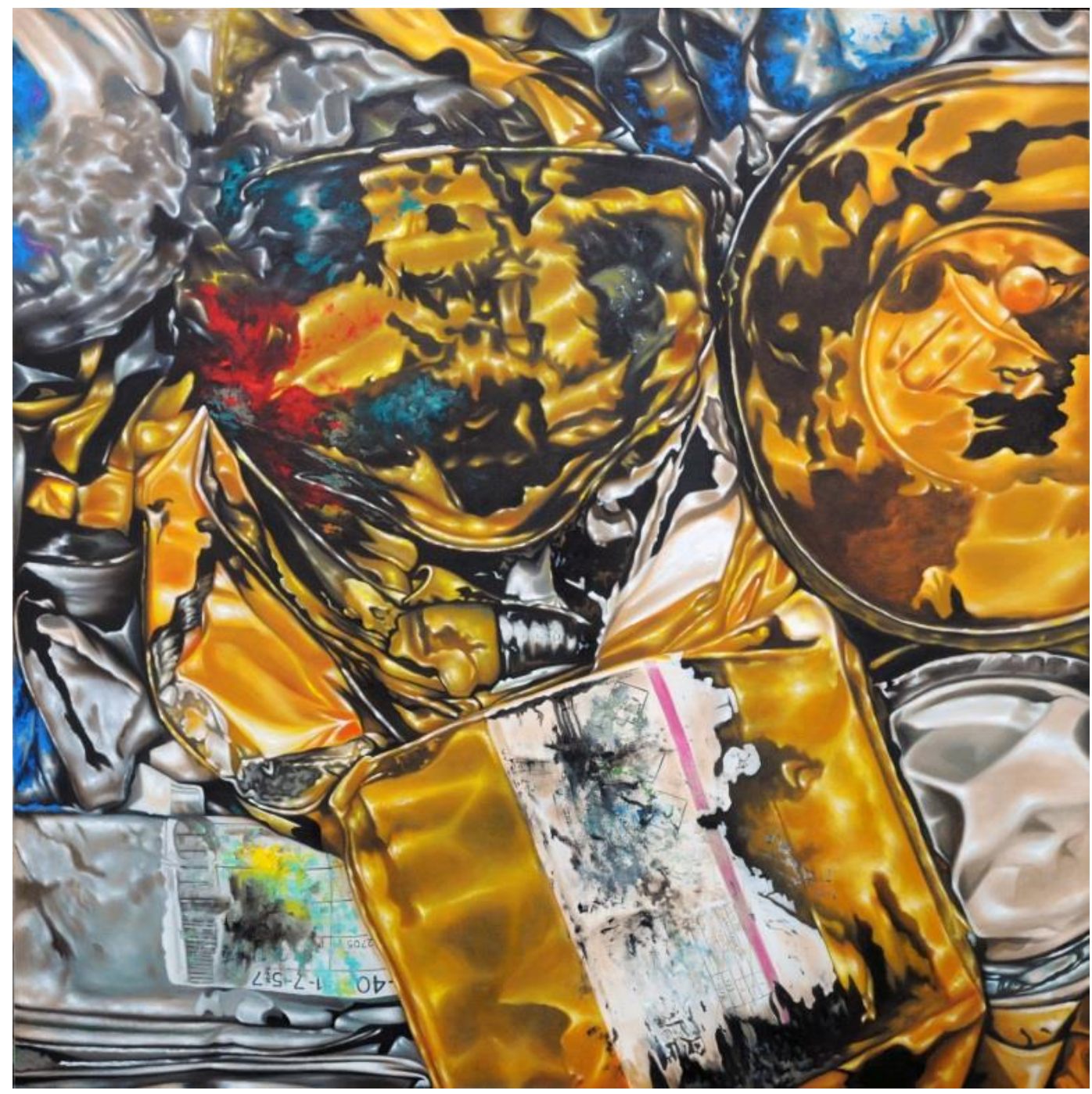

Gambar 4 Arya Sudrajat, Brutto part 2, 2017, cat minyak di kanvas, 190x190 cm. Foto: Selasar Sunaryo Art Space

membuat corak lukisan "yang lain" melalui interaksi dari pelukis-pelukis lain di luar Jelekong. Di antara pelukis-pelukis di luar Jelekong itu adalah pelukis-pelukis hasil didikan pendidikan tinggi seni rupa dan kampus-kampus seni rupa di Indonesia terletak di kotakota besar.

Jadi, meski tetap diproduksi di Desa Jelekong oleh para pelukis Jelekong pula, tapi para pelukis tersebut dapat diakatakan "mengadopsi" pengetahuan dan selera masyarakat menengah atas kota. Wacana dan gagasan-gagasan seni rupa kontemporer tidak bisa abai begitu saja dari apa yang terjadi di luar negeri, terutama negara-negara maju yang memiliki perkembangan wacana seni rupa yang baik dan maju pula. Seni rupa kontemporer tidak bisa terpisah begitu saja dari wacana seni rupa global. Sementara itu, praktek seni rupa kontemporer di Indonesia berpusat di kota-kota besar. Publik (konsumen) bagi karya-karya seni rupa itu pun adalah sekumpulan publik yang eksklusif, tidak saja karena jumlahnya sangat kecil dibanding keseluruhan masyarakat Indonesia tapi sebagian besar publik itu pun terdapat di kota-kota besar pula.

Di tengah-tengah medan yang seperti itu, para pelukis Jelekong pun harus membawa lukisan-lukisan mereka ke luar dari Jelekong dan menuju pusat-pusat seni rupa 
kontemporer -yaitu kota-kota besar. Maka, para pelukis tersebut misalnya, membawa memamerkan- karya-karya mereka di galeri-galeri yang ada di Bandung, Jakarta atau Jogja. Dengan begitu, pelukis mulai berhubungan dengan sistem dalam seni rupa kontemporer. Pelukis Jelekong kontemporer kini harus menjalin hubungan dengan galerigaleri seni, sebagai pihak yang akan mendistribusikan -menjual- karya mereka. Di dalam mekanisme ini, hubungan antara pelukis dan galeri biasanya terikat dalam sebuah sistem yang formal, tidak jarang hubungan kerjasama tersebut tertuang dalam sebuah surat kontrak. Pembagian hasil penjualan lukisan pun sudah diatur dengan jelas.

Berhubungan dengan mekanisme galeri, sorang pelukis Jelekong kontemporer juga dituntut untuk produktif. Meskipun, artian produktif dalam medan seni lukis semacam ini, bukanlah memproduksi lukisan dalam jumlah ratusan dalam hitungan bulan misalnya. Di dalam medan seni lukis kontemporer, produktifitas semacam itu tidak diharapkan, mengingat dalam medan seni lukis ini, lukisan yang dihasilkan tidak bisa lepas dari perkara standar kualitas serta faktor-faktor seperti kebaruan, kesegaran serta eksperimentasi. Untuk memenuhi hal-hal tersebut, pelukis membutuhkan banyak asupan informasi, nasihat, pertimbangan hingga evaluasi terhadap lukisannya, dan berbagai asupan tersebut bisa datang dari sesame seniman, kurator, kritikus, kolektor dan sebagainya. Di situ, seorang pelukis butuh untuk menyisihkan waktu untuk bergaul dan berinteraksi di dalam medan.

Berkaitan dengan perkara ekonomi dalam medan seni lukis kontemporer, pelukis Jelekong juga berhadapan dengan sistem yang berbeda. Di dalam medan seni lukis ini, eksklusifitas menjadi penting, jumlah lukisan seorang pelukis yang beredar dalam medan juga mesti berbatas. Medan yang eksklusif, juga berhubungan dengan harga karya yang eksklusif. Sebuah lukisan dalam medan seni lukis ini, bisa berharga puluhan kali lipat dari harga sebuah lukisan dalam medan seni lukis yang satu -medan di mana lukisan tradisional Jelekong beredar. Di dalam medan lukis ini, progres peningkatan harga lukisan seorang pelukis juga adalah variabel yang penting untuk melihat sebuah lukisan adalah sesuatu yang bernilai atau tidak. Harga lukisan seorang pelukis diharapkan dapat selalu meningkat seiring rekognisi yang akan didapatkan oleh pelukisnya dalam medan. Dalam hal ini, rekam jejak (curriculum vitae) pelukis serta portofolio yang dimilikinya menjadi hal yang juga penting.

\section{SIMPULAN}

Sebagai sebuah "tradisi" yang sudah berkembang sejak sekitar 30 tahun lalu, melukis sudah memiliki peran penting dalam keseharian masyarakat Kampung Jelekong. Tidak saja menjadi ikon pariwisata kampung tersebut, melukis dan lukisan sudah menjadi mata pencaharian utama bagi sebagian masyarakat Jelekong. Menjadi pelukis tidak saja adalah pilihan profesi bagian sebagian masyarakat Jelekong, lain dari itu pelukis juga seringkali dianggap sebagai "bakat bawaan" dalam masyarakat Jelekong. Hidup di tengah-tengah aktivitas melukis, serta ikut terlibat dalam proses sehubungan dengan itu, menjadikan melukis adalah pekerjaan yang boleh jadi dekat dengan seorang pelukis Jelekong bahkan sejak ia masih kecil.

Lukisan Jelekong sudah cukup dikenal luas selama puluhan tahun, terutama kaitannya dengan ciri khasnya pada visual-visual tertentu dalam lukisannya, seperti: pemandangan alam, binatang atau bunga. Namun, di dalam dinamikanya belakangan, tidak saja hanya ada satu macam lukisan yang berkembang di Jelekong. Pertemuan antara kemampuan "bakat"- serta kebiasaan melukis yang dipelajari turun temurun dengan wawasan baru yang didapat melalui interaksi dengan berbagai pihak, kini muncul pula pelukis-pelukis Jelekong yang membuat macam lukisan yang lain, yang berbeda dari sebelumnya. Maka kini ada dua macam lukisan yang dibuat para pelukis Jelekong: lukisan "tradisional" Jelekong dan lukisan "kontemporer" Jelekong. 
Meskipun kedua macam lukisan tersebut sama-sama dibuat oleh pelukis Jelekong, namun pada dasarnya kedua jenis lukisan tersebut memiliki banyak perbedaan. Beberapa aspek perbedaan tersebut dapat dijelaskan sebagai berikut;

\section{Objek, tema dan material lukisan}

Lukisan Jelekong, selama puluhan tahun dikenal luas oleh publik seni rupa sebagai lukisan-lukisan yang memiliki ciri khas pada objek atau tema yang dilukis. Secara umum, lukisan "tradisional" Jelekong menampilkan tema pemandangan alam, dengan beberapa objek utama: gunung, hamparan sawah, padi menguning, sungai, pepohonan; binatang: sekumpulan ikan koi, kuda, burung; tanaman: bunga dalam vas, bunga anggrek; alam benda; juga lukisan abstrak.

Sementara itu lukisan "kontemporer" Jelekong memiliki objek dan tema yang lebih cari dan beragam. Objek dan tema dalam lukisan bergantung pada ketertarikan dan gagasan masing-masing pelukis dalam merespon lingkungan sekitarnya. Objek lukisan ini dapat beraneka ragam, dari manusia, hewan, abstrak, tulisan, aneka benda, landscape hingga figure-figur fantasi. Pada sisi tema, tema yang diangkat pun bisa sangat beragam, dari tema personal seperti persoalan keluarga, memori masa kecil; hingga masalah sosial seperti isu lingkungan, kritik sosial politik dan sebagainya.

Pelukis kontemporer Jelekong, bahkan dalam kekaryaannya tidak lagi berhenti pada lukisan cat di atas kanvas. Beberapa juga melakukan eksperimen dan eksplorasi dalam material seperti melukis di atas papan, plat, akrilik; menggunakan aneka macam cat seperti cat minyak, cat akrilik, cat besi, cat semprot; serta mencampur lukisannya dengan berbagai barang temuan. Lebih jauh, eksperimen mereka juga tiba pada bentukan karya selain lukisan, diantaranya: objek 3 dimensi, instalasi hingga performans.

\section{Tujuan dan dorongan melukis}

Perbedaan pada poin pertama di atas, dipengaruhi pula oleh dorongan serta posisi aktivitas melukis bagi para pelukis. Lukisan "tradisional" Jelekong tentu saja utamanya bersangkut paut dengan urusan ekonomi dan pariwisata (turisme) yang sudah berlangsung lama. Karena itu, pangsa pasar untuk lukisan ini selalu ada dan cenderung tetap, baik dari segi peruntukan dan selera. Oleh karena itu, para pelukis lukisan ini cenderung bertahan pada tema-tema dan teknik tertentu. Hanya sedikit sekali eksperimentasi di dalamnya. Pada lukisan jenis ini, eksperimentasi dan eksplorasi bukanlah yang utama. Dalam beberapa hal, "pakem" lukisan menjadi yang utama karena proses apresiasi dan jual-beli beberapa tema lukisan, berkaitan dengan kepercayaan para pembeli tentang feng-shui dan hoki (keberuntungan). Seperti pada tema-tema lukisan ikan koi dan kuda.

Di sisi lain, lukisan "kontemporer" Jelekong tidak lagi berkaitan dengan perkara pariwisata (turisme), meski dalam bentuk yang lain ia tetap berurusan dengan perkara ekonomi. Di dalam prinsip seni macam ini, lukisan dianggap sebagai perwujudan ekspresi personal pelukis dalam menghadapi segala fenomena yang ada di sekitarnya. Oleh karena itu, lukisan tiap pelukis adalah khas. Ciri dan corak personal pelukis menjadi penting di sana. Selain itu, progres atau capaian artistik menjadi faktor yang penting dalam penilaian terhadap seorang pelukis. Oleh karena itu, eksperimentasi dan ekplorasi adalah hal yang tidak terhindarkan dan bahkan sebuah keharusan. Kecenderungan untuk diam pada satu tema, dapat berujung pada anggapan mandek dan tidak progresif, dan ini adalah penilaian yang buruk bagi seorang pelukis.

\section{Medan seni lukis; mekanisme dan sistem}

Bagaimana dan untuk apa lukisan-lukisan tersebut diperjual-belikan akan bergantung pada di mana lukisan tersebut berada. Kedua macam lukisan Jelekong yang berbeda tersebut dengan demikian juga berada di dalam medan seni lukis yang berbeda pula. Perbedaan medan seni inilah yang mengakibatkan kedua macam lukisan Jelekong 
tersebut diperlakukan secara berbeda pula. Medan yang berbeda juga menyebabkan perbedaan dalam hal alasan dan tujuan suatu lukisan diperjual-belikan.

Lukisan "tradisional" terkait dengan medan seni lukis yang erat kaitannya dengan pariwisata (turisme). Di dalam medan semacam itu, lukisan dipandang sebagai souvenir atau cenderamata. Pada ujungnya, lukisan boleh jadi berfungsi sebagai benda pajangan yang dapat memperindah ruangan dan akan mampu mengingatkan pemiliknya pada kenangan pada suatu tempat. Lukisan ini juga bergerak dalam sistem produksi-distribusikonsumsi yang cenderung sederhana dan tetap (melibatkan: pelukis-pengepul-pembeli).

Sementara itu, di dalam medan yang lain -medan seni lukis kontemporer- lukisan dipandang sebagai sebuah benda unik yang diproduksi oleh pelukis. Benda ini juga dipandang sebagai cerminan dan perwujudan gagasan serta ekspresi pelukis. Karena pandangan demikian, sebuah lukisan semacam ini dapat dihargai dengan harga yang sangat tinggi, bergantung pada tingkat rekognisi pelukisnya. Pada tingkatan tertentu, dalam medan seni lukis ini, lukisan pada akhirnya juga dipandang sebagai sebuah benda yang memiliki nilai investasi. Pada titik ini, progres kenaikan harga jual lukisan seorang pelukis menjadi hal yang sensitif dan penting. Di dalam medan seni lukis ini, lukisan dapat bergerak dalam sistem produksi-distribusi-konsumsi yang cenderung lebih kompleks dibanding dalam medan yang satu. Sistem dan mekanisme tersebut dapat berubah-ubah dan mungkin melibatkan lebih banyak pihak (seperti: pelukis, galeris, dealer, balai lelang, art fair, kolektor, spekulan, museum).

Perbedaan medan seni lukis tersebut, juga menyebabkan perbedaan cara dan perilaku pelukis Jelekong di dalam masing-masing medan. Hal tersebut disebabkan karena dalam medan seni lukis yang berbeda, akan dihadapi pula para pelaku dengan habitus masingmasing yang berbeda pula. Terdapat perbedaan motivasi, tujuan, sistem, mekanisme, ukuran-ukuran serta nilai-nilai.

Apa yang telah disebutkan di atas, adalah perbedaan-perbedaan mendasar yang ditemukan dari kedua macam alur perkembangan lukisan Jelekong yang ada hari ini. Keberadaan dua alur dalam lukisan Jelekong, menunjukkan perkembangan visi dan misi para pelukis di kampung tersebut. Perkembangan yang membawa masing-masing pelukis dalam kedua alur tersebut menempuh resiko serta konsekuensi yang berbeda pula. Pada alur yang pertama, alur di mana lukisan "tradisional" Jelekong berada, Jelekong bisa jadi identitas adalah ciri khas yang penting dalam lukisan. Sementara pada alur yang kedua, yang ditempuh oleh lukisan "kontemporer" Jelekong, Jelekong boleh jadi hanyalah sekedar "identitas" dari mana seorang pelukis berasal, karena di sana, identitas serta ciri khas artistik personal mempunyai peran yang penting dan utama.

\section{UCAPAN TERIMAKASIH}

Di dalam penulisan artikel ini, penulis ingin mengucapkan terima kasih kepada beberapa pihak yang sudah berkontribusi dalam penulisan artikel ini. Ucapan terima kasih, penulis sampaikan kepada pihak Selasar Sunaryo Art Space yang telah memberikan kesempatan untuk terlibat dalam program residensi Transit \#4: Jelekong Spektrum, yang mana semenjak dari situ penulis mulai bersentuhan dengan lukisan Jelekong. Juga untuk izin menggunakan foto dokumentasi yang menjadi koleksi Selasar Sunaryo Art Space untuk keperluan penulisan artikel ini. Ucapan terima kasih juga penulis ucapkan kepada Hedi Sutardja, Arya Sudrajat, Inovic Dhu dan Ahmad Munir yang telah menceritakan banyak hal berkaitan dengan kehidupan melukis di Jelekong. Terakhir, ucapan terima kasih juga penulis ucapkan kepada segenap anggota Kelompok Keilmuan Estetika dan Ilmu-ilmu Seni, Seni Rupa ITB yang telah mendorong terbentuknya semangat dan produktivitas dalam membuat tulisan di Jurnal serta memproduksi pengetahuanpengetahuan tentang seni rupa Indonesia. 
DAFTAR PUSTAKA

[1]. Nur R. 1986. Lukisan Desa Jelekong Kabupaten Bandung. Skripsi. Institut Teknologi Bandung;

[2]. Yuliman S. 1989. Medan Seni Lukis Kita: Permasalahan. Forum Seni Rupa Indonesia. Jakarta;

[3]. Hujatnika A. 2015. Kurasi dan Kuasa. Jakarta: Marjin Kiri;

[4]. Yuliman S. 1989. Dua Seni Rupa. In: Simposium Nasional Seni Rupa. Surabaya: Dewan Kesenian Surabaya; 